\title{
Productivity improvement: Implementation and analysis of clustering technique in manufacturing of timing gearbox cover
}

\author{
Satbir Singh $^{\mathrm{a}^{*}}$ and Sandeep Singhal ${ }^{\mathrm{b}}$
}

${ }^{a}$ Department of Mechanical Engineering, Ambala College of Engineering \& Applied Research Mithapur (Ambala) 133101

${ }^{b}$ Department of Mechanical Engineering, National Institute of Technology, Kurukshetra -136119

\section{H R O N I C L E \\ A B S T R A C T}

Article history:

Received October 28, 2015

Received in revised format

November 28, 2015

Accepted January 25, 2016

Available online

January 25, 2016

Keywords:

Inventory

Labor productivity

Material productivity

Manufacturing cost

\begin{abstract}
Productivity is an indicator of efficiency with which resources, both human and material, are transformed into useful services and goods. The vital purpose of the prevailing work was to analyze the factors involved in the improvement of productivity in all its types such as material, capital, labor, machine and total productivity at the plant. This was obtained by decreasing the manufacturing cost per component by reducing its cycle time and increasing the monthly production rate. The experimentation revealed that using proposed processes and improved tooling, monthly production rate has increased by $16.2 \%$ due to reduced cycle time, the number of defected components i.e. rejection rate has reduced up to $2 \%$. A reduction of $6.78 \%$ in manufacturing cost per component was recorded. Tooling cost has reduced by more than $12 \%$. Saving up to $50 \%$ in inspection cost has been recorded due to close dimensional tolerances and high surface finish achieved on components. An increase of $4.84 \%$ was recorded in total productivity.
\end{abstract}

\section{Introduction}

'Productivity' has become a versatile word as by and large everyone talks about it. The meaning of "productivity" is different for different people. Consequently, it varies from efficiency to effectiveness. Productivity is a measure of the efficiency with which a company or an enterprise converts its available resources (inputs) into finished goods or services i.e. required outputs.Measurement of productivity commonly supposed to be a ratio of outputs produced to resources consumed (Card, 2006). The ratio of output quantity index to the input quantity index is the measuring tool for productivity change (Balk, 2005) thus a total productivity measure reflects combined impact of all the inputs in producing the output. To measure productivity for multiproduct firms (Berndt \& Fuss, 1989), productivity can be enhanced by producing more output with the same input or by producing the same output with fewer inputs. Productivity can be defined as human efforts to produce more and more with less and less

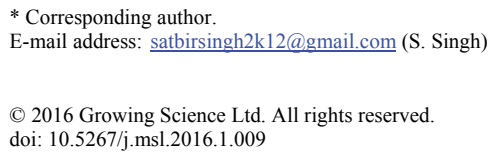


inputs of resources as a result of which the production benefits are distributed among maximum number of people.

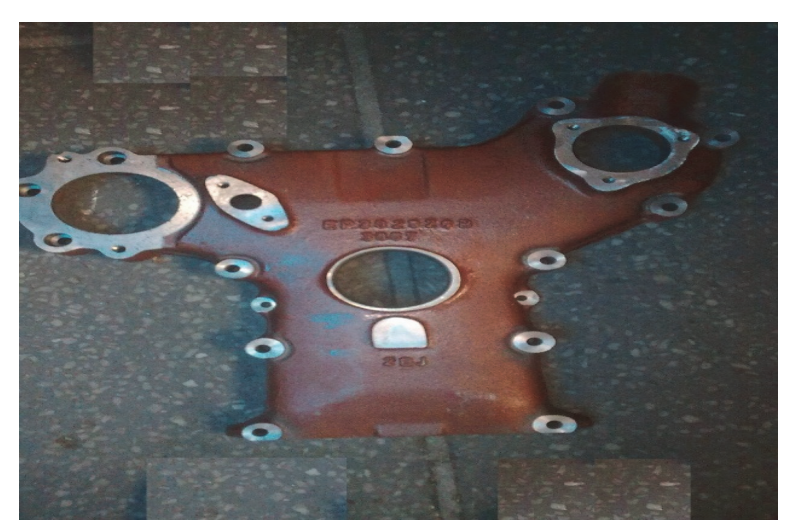

Fig. 1(a). Timing gear box cover- outer side

Productivity can be increased by reducing the cycle time and controlling the process statistically (Sheth \& Sisodia, 2002; Sharma et al., 2012). Different productivity improvement strategies have been implemented in SMEs (Gunasekaran \& Cecille, 1998). Reduction in waste and subsequently reduced cycle time leads to the productivity improvement (Amir Hanin, 2007). Automation in process proved to be more productive, hence yielding the productivity values (Bryson et al., 2005) Productivity is constant adaptation of social and economic life to changing conditions. It is the continual effort to apply new techniques and methods. The means of productivity is balance between the entire factors of production that will give maximum output with the smallest effort. The ratio of output to one class of input is partial productivity. For example, labor productivity which is ratio of output to labor input is a partial productivity measure.

As a policy perspective, it is typical to understand which factors underlie the difference in productivity across firms and which are associated with higher productivity (Fernandez, 2008; Singh and Singhal, 2015). The ratio of net output to the sum of associated labor and capital (factor) inputs is total factor productivity. The effect of import liberalization on productivity growth in Indian industries in 1990s has been studied and concluded that trade liberalization did have a positive effect on industrial productivity (Goldar \& Kumari, 2002; Goldar, 2004). Net output means total output minus intermediate goods and services purchased. The ratio of total output to the sum of all input factors is total productivity. The impact of the economic liberalization on manufacturing productivity in the industrial sector has been analyzed (Das, 2003). It has been found that in-process inventory reduction stimulated gain in productivity (Lieberman \& Demeester, 2002). Greater productivity means accomplishing more science with less cost and effort (Faulk et al., 2004). More accountability is required from the employee by providing more responsibility to them by the employer, consequently increasing the productivity and retention of hourly employees (Bond \& Galinsky, 2006). Technical innovation viz. information resources, technology acquisition, technological cooperation, patents, governmental support, influence productivity improvement (Doo \& Sohn, 2008). A more sustainable and high productivity production system can be developed to determine the productivity level of the industry. If the fixed costs are considered, the profit of the average farm is negative (Mohaddes \& Mazhari, 2008). Partial productivity and total factor productivity for total manufacturing sector decelerate during the post reform period (Kaur \& Kiran, 2008). It is concluded that changing ownership by converting large number of firms to stock-holding companies positively contribute to growth in aggregate productivity (Motohashi \& Yuan, 2009). Average productivity of India's manufacturing firms has been increased by unilateral reduction in final goods tariffs (Nataraj, 2009). The results indicate that the TFP growth of Indian industry primarily for the formal sector has positively affected by SBR (Kathuria et al., 2010). Most of the papers have stressed that aggregate TFP in a country can be reduced by misallocation of inputs across 
the firms. Resource reallocation can increase aggregate total factor productivity (Hsieh \& Klenow, 2007). The combination of unavailability of credit and high inflation aggravated distortion and further lowered the productivity growth (Gupta, 2010). Measurement of output is not a depending factor significantly for TFPG estimates (Dash et al., 2010). Focusing attention on manufacturing productivity or the overall production efficiency as the key indicator of competitive ability and strength, overall performance could be improved (Sohail, 2006).

\section{Problem formulation}

Problem formulation describes a brief background of the automobile parts manufacturing company and importance of achieving / maintaining high quality production. Further it relates to our specific study and leads to our problem definition. As to start defining a problem; first part of the research is to conduct a pre study in order to understand the manufacturing process in a better way and to find possible aspects affecting the productivity performance of industry or company. The various operations on different machines using conventional techniques require/ consume more time, space, labor cost, material handling cost, shipping cost and hence total production cost is combination of all of the above mentioned factors and productivity is a dependent term on different aspects. Requirement of the modern manufacturing is to achieve high productivity and consequently to reduce unit production cost. This necessitates some improved manufacturing methods or techniques to be devised for manufacturing the required parts or components. Resources need to be utilized effectively and work holding devices to be efficient ensuring quick loading / unloading to speed up manufacturing operation.

The present work was carried out in a tractor parts manufacturing company near Ambala City of Haryana (India), where the management of the company desired that with the existing resources; productivity be increased by reducing the lead time of complex shaped components, increase the production of such vital component i.e. Timing Gear Box Cover and also monthly rejection rate be reduced by clustering different operations and performing maximum clustered operations on a single $\mathrm{CNC}$ machine comprising the required facilities.

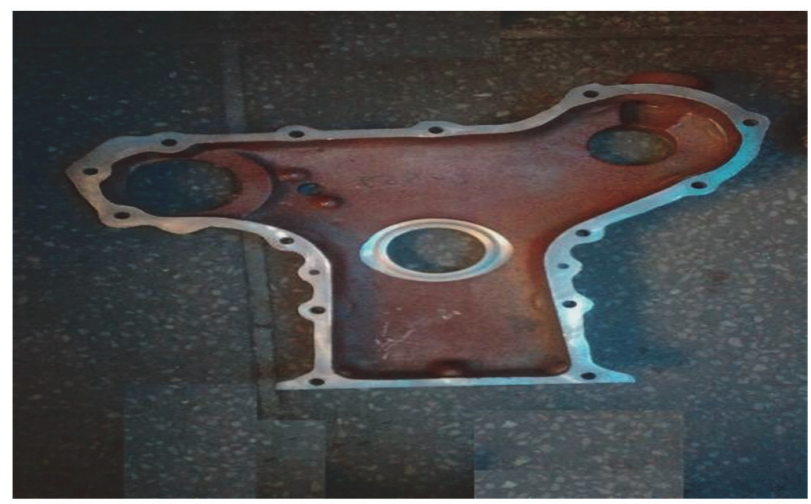

Fig. 1(b). Timing gear box cover- inner side

\section{The proposed study}

For Existing Manufacturing Process, various components manufactured by the company and the machinery/equipment installed at the company were studied. Main component among the automobile parts manufactured by the company i.e. Timing Gearbox Cover has been shown in Fig. 1(a) and Fig. 1 (b), respectively. Operation time chart for vital component Timing Gearbox cover is shown in Table 1. Table 1 shows existing operations with their sequence, different machines needed, machine hour rate, time elapsed on each of the machines to perform the required operation, machining cost per component, helper cost and in-plant material handling cost in manufacturing the so-called vital component Timing Gearbox Cover. 
Table1

Operation time chart for timing gearbox cover using the existing process

\begin{tabular}{|c|c|c|c|c|c|c|c|}
\hline $\begin{array}{l}\text { Op. } \\
\text { No. }\end{array}$ & Description of Operation & Machine Tool & $\begin{array}{l}\mathrm{M} / \mathrm{c} \\
\text { Hour } \\
\text { Rate } \\
\text { (Rs) } \\
\end{array}$ & $\begin{array}{c}\text { Time Elapsed on } \\
\text { Machine(Minutes) }\end{array}$ & $\begin{array}{c}\text { Machining } \\
\text { Cost per } \\
\text { Component } \\
\text { (Rs) }\end{array}$ & $\begin{array}{c}\text { Helper } \\
\text { cost } \\
\text { (Rs) }\end{array}$ & $\begin{array}{c}\text { In Plant Material } \\
\text { Handling/Shipping } \\
\text { Cost (Rs) }\end{array}$ \\
\hline 1 & Rough Facing of Joint Face & C- Lathe & $80 /-$ & 18.5 & 24.66 & NIL & 1.00 \\
\hline 2 & Rough Milling Top Face & V-Milling & $100 /-$ & 4.6 & 7.66 & NIL & 1.00 \\
\hline 3 & $\begin{array}{l}\text { Rough and Finish Mill Joint Face, drilling } 14 \text { holes } \varnothing \\
10.5\end{array}$ & $\mathrm{VMC}-800$ & $350 /-$ & 10.2 & 59.5 & 2.57 & 1.00 \\
\hline 4 & $\begin{array}{l}\text { Finish Mill Top Face, Rough \& Finish bore } \varnothing 82.55 \\
\text { H8, Ø } 72 \text { H8 and Ø } 20 \text { H11 }\end{array}$ & $\mathrm{VMC}-550$ & $400 /-$ & 12.4 & 82.66 & 3.1 & 1.00 \\
\hline 5 & Rough Milling Sump Face & H-MILL & $100 /-$ & 3.6 & 6.00 & 0.875 & 0.50 \\
\hline 6 & Finish Milling Sump Face & H-MILL & $100 /-$ & 2.7 & 4.5 & 0.675 & 1.00 \\
\hline 7 & Milling and Boring of Breather of bore $\varnothing 45 \mathrm{H} 8$ & VMC-840 & $325 /-$ & 6.0 & 32.5 & 1.45 & NIL \\
\hline 8 & Drilling, C'bore and Tap 3 holes M 10 & R-Drilling & $100 /-$ & 4.7 & 7.83 & 1.17 & 0.50 \\
\hline $8 \mathrm{a}$ & Opening of drill 14 Holes $\varnothing 10.5$ & R-Drilling & $100 /-$ & 4.4 & 7.33 & NIL & 1.00 \\
\hline 9 & Tap 5 Holes M8, Spot Face 11 Holes Ø28 & R-Drilling & $100 /-$ & 3.7 & 6.16 & 0.95 & 0.50 \\
\hline 10 & C' Boring of 3 Holes $\varnothing 18.0$ (bolt holes) & R-Drilling & $100 /-$ & 2.5 & 4.16 & NIL & 1.00 \\
\hline 11 & Mill Boss for Clearance of Water Pump Mounting & H-Milling & $100 /-$ & 1.8 & 2.0 & 0.45 & 0.50 \\
\hline 12 & Turning of $\varnothing 84$ Holes & C-Lathe & $80 /-$ & 3.6 & 4.8 & NIL & 1.00 \\
\hline 13 & D’Buring\& Cleaning, Check Leakage, \& Dimensions 28 & Manual & NIL & 2.0 & 3.0 & 2.5 & 1.00 \\
\hline 14 & Final Inspection & Manual & NIL & 2.0 & NIL & 1.5 & 1.00 \\
\hline
\end{tabular}

Following necessary assumptions have been considered in preparing the operation time chart mentioned in said Table.

- Machine hour rate for different machines shown in Table includes purchasing cost of machine, interest, wages incurred, power consumed, and cost of tooling, depreciation and miscellaneous expenditures/overheads.

- Cost of machining was calculated by multiplying machine hour rate with time elapsed on each of machines for performing different operations required to manufacture the said component.

- The manufacturing cost for the component comprising of machining cost, helper cost and inplant material handling/shipping cost.

- In plant material handling cost has been taken asRs1/-for movement of comparatively longer distance and Rs 0.50 for smaller distance movement between various machines.

- Helper rate was considered as Rs15 per hour.

\section{Data-Collection}

Data pertaining to production with corresponding rejections for the main component i.e. Timing Gearbox Cover was collected on monthly production basis for the last more than 1 year with existing and improved process to study and analyze the defects produced and is shown in Tables 2 and Table 3 , respectively. The existing production/ rejection trend for 9 months i.e. from Apr, 2013 to Dec, 2013 has been shown in the Table 2 .

Table 2

Monthly Production / rejection trend for Existing Process.

\begin{tabular}{ccc}
\hline Month & \multicolumn{2}{c}{ Timing Gearbox Cover } \\
\cline { 2 - 3 } & Production & Rejection \\
\hline April, 2013 & 2400 & 108 \\
May, 2013 & 2500 & 80 \\
June, 2013 & 2200 & 104 \\
July,2013 & 2300 & 112 \\
Aug, 2013 & 2500 & 106 \\
Sep, 2013 & 2400 & 117 \\
Oct, 2013 & 2500 & 105 \\
\hline Nov, 2013 & 2400 & 98 \\
\hline Dec, 2013 & 2350 & 90 \\
\hline
\end{tabular}

Subsequently Table 3 shows production/ rejection trend for another 9 months i.e. from March, 2014 to Nov, 2014 using the improved process. 
Table 3

Monthly Production / rejection trend for Improved Process

\begin{tabular}{ccc}
\hline Month & Timing Gearbox Cover & \\
& Production & Rejection \\
\hline March, 2014 & 2750 & 55 \\
April,2014 & 2875 & 58 \\
May, 2014 & 2500 & 52 \\
June, 2014 & 2700 & 55 \\
July, 2014 & 2900 & 60 \\
Aug, 2014 & 2700 & 56 \\
Sep, 2014 & 2850 & 57 \\
Oct, 2014 & 2725 & 56 \\
Nov, 2014 & 2600 & 53 \\
\hline
\end{tabular}

The existing material productivity, labor- capital- machine productivity and total productivity has been calculated on the monthly production basis for main component viz. Timing Gearbox Cover and is shown in Table4 which is based on the following information given by the accounts department of company;

Selling Price per component (Rs) : :975=00

Material Cost per component (Rs) $\quad: 625=00$

Manufacturing Cost per component (Rs) : $280=00$

Table 4

Existing material, labor-capital-machine and total productivity

\begin{tabular}{|c|c|c|c|c|c|c|}
\hline Month & $\begin{array}{l}\text { Revenue from } \\
\text { Production } \\
\text { (Rs) } \\
\text { [a] }\end{array}$ & $\begin{array}{l}\text { Material Cost } \\
\qquad \begin{array}{c}\text { (Rs) } \\
{[\mathrm{b}]}\end{array}\end{array}$ & $\begin{array}{l}\text { Labor, Capital \& } \\
\text { Machining Cost } \\
\text { (Rs) } \\
\text { [c] }\end{array}$ & $\begin{array}{c}\text { Material } \\
\text { Productivity } \\
\\
{[\mathrm{a} / \mathrm{b}]}\end{array}$ & $\begin{array}{c}\text { Labor, Capital } \\
\text { and Machine } \\
\text { Productivity } \\
{[\mathrm{a} / \mathrm{c}]}\end{array}$ & $\begin{array}{c}\text { Total } \\
\text { Productivity } \\
{[\mathrm{a} / \mathrm{b}+\mathrm{c}]}\end{array}$ \\
\hline April, 2013 & 2234700 & 1500000 & 672000 & 1.4898 & 3.3254 & 1.0288 \\
\hline May, 2013 & 2340000 & 1562500 & 700000 & 1.4976 & 3.3428 & 1.0342 \\
\hline June, 2013 & 2067000 & 1375000 & 616000 & 1.5032 & 3.3555 & 1.0381 \\
\hline July, 2013 & 2141100 & 1437500 & 644000 & 1.4894 & 3.3246 & 1.0286 \\
\hline Aug, 2013 & 2328300 & 1562500 & 700000 & 1.4901 & 3.3261 & 1.0290 \\
\hline Sep, 2013 & 2236650 & 1500000 & 672000 & 1.4911 & 3.3283 & 1.0297 \\
\hline Oct, 2013 & 2327325 & 1562500 & 700000 & 1.4894 & 3.3247 & 1.0286 \\
\hline Nov, 2013 & 2237625 & 1500000 & 672000 & 1.4917 & 3.3297 & 1.0302 \\
\hline Dec, 2013 & 2195700 & 1468750 & 658000 & 1.4949 & 3.3369 & 1.0324 \\
\hline
\end{tabular}

\section{Methods to Reduce Rejection Rate}

$>$ Rejection rate has been reduced on monthly basis by clustering some of the operations required to manufacture the component and performing all the clustered operations in a single set up on CNC machine equipped with all the intended facilities.

$>$ Due to reduced number of set-ups probability of error got reduced.

$>\mathrm{CNC}$ machine proved to be more rigid then the conventional machines, hence close dimensional tolerances are attained on the components, consequently rejection rate is reduced.

> An extendable universal fixture has-been developed to ensure quick and easy supporting, firm holding and rigid clamping of the so called semi-finished component during its manufacturing.

Operation time chart for the said component timing gearbox cover using improved process has been shown in Table 5. 
Table 5

Operation time chart for improved process

\begin{tabular}{|c|c|c|c|c|c|c|c|}
\hline $\begin{array}{l}\text { Op. } \\
\text { No }\end{array}$ & Description & $\begin{array}{l}\text { Machine } \\
\text { Tool }\end{array}$ & $\begin{array}{l}\text { M/c } \\
\text { Hour } \\
\text { Rate } \\
\text { (Rs) }\end{array}$ & $\begin{array}{l}\text { Ave. Cycle } \\
\text { Time } \\
\text { (Minutes) }\end{array}$ & $\begin{array}{l}\text { Cost Per } \\
\text { Compo- } \\
\text { nent(Rs) }\end{array}$ & $\begin{array}{l}\text { Help-er } \\
\text { cost } \\
\text { (Rs) }\end{array}$ & $\begin{array}{l}\text { In Plant } \\
\text { Material } \\
\text { Handling } \\
\text { Cost (Rs) }\end{array}$ \\
\hline 1 & Rough Facing/ machining of Joint Face & C- Lathe & $80 /-$ & 18.5 & 24.66 & NIL & 1.00 \\
\hline 2 & Rough Milling Top Face & V-Milling & $100 /-$ & 4.6 & 7.66 & NIL & 1.00 \\
\hline 3 & Rough \& Finish Mill Joint Face, drill 14 holes $\varnothing 10.5$ & $\mathrm{VMC}-800$ & $350 /-$ & 10.2 & 59.5 & 2.57 & 1.00 \\
\hline 4 & $\begin{array}{l}\text { Finish Mill Top Face, Rough \& Finish bore } \varnothing 82.55 \\
\mathrm{H} 8, \varnothing 72 \mathrm{H} 8 \text { and } \varnothing 20 \mathrm{H} 11\end{array}$ & $\mathrm{VMC}-550$ & $400 /-$ & 12.4 & 82.66 & 3.1 & 1.00 \\
\hline 5 & $\begin{array}{l}\text { Rough Mill Sump Face, Finish Mill Sump Face, } \\
\text { Milling and Boring of Breather, Ø } 45 \text { H8, Drill, C'bore } \\
\text { and Tap } 3 \text { holes M 10, Mill Boss for Clearance of Water } \\
\text { Pump Mounting }\end{array}$ & HMC-440 & $450 /-$ & 5.4 & 40.50 & 0.95 & NIL \\
\hline 6 & Opening of drill 14 Holes $\varnothing 10.5$ & R-Drilling & $100 /-$ & 4.4 & 7.33 & NIL & 1.00 \\
\hline 7 & Tap 5 Holes M8, Spot Face 11 Holes Ø28 & R-Drilling & $100 /-$ & 3.7 & 6.16 & 0.95 & 0.50 \\
\hline 8 & C' Boring of 3 Holes $\varnothing 18.0$ (bolt holes) & R-Drilling & $100 /-$ & 2.5 & 4.16 & NIL & 0.50 \\
\hline 9 & Turning of $\varnothing 84$ Holes & C-Lathe & $80 /-$ & 3.6 & 4.8 & NIL & 1.00 \\
\hline 10 & D’Buring, Cleaning, Check Leakage, \& Dimension 28 & Manual & NIL & 2.0 & 3.0 & 2.5 & 1.00 \\
\hline 11 & Final Inspection & Manual & NIL & 2.0 & NIL & 1.5 & 1.00 \\
\hline
\end{tabular}

\section{Improvement of Productivity Using Developed Fixture}

Use of the developed universal fixture for manufacturing the above mentioned component Timing Gearbox Cover has reduced number of machines from eight to six because of clustering. Despite of using higher hourly rate machine, the manufacturing cost per component has reduced due to less machining and helper cost on account of reduced cycle time, as compared with earlier manufacturing cost per component. Operation number 5,6,7,8 and 11 shown in Table I are clustered and performed in a single set up on HMC, and are shown by a single operation 5 in Table5). Cycle time of manufacturing the main component has reduced tremendously causing proportionate increase in monthly production and consequently in monthly productivity. Monthly Material, Labor- Capital- Machine and Total Productivity using improved process has been calculated on the basis of following reduced elements of cost and is shown in Table 6. Manufacturing cost per component has reduced considerably due to the reduction in cycle time.

Selling Price per component (Rs) : $\quad: 975=00$

Material Cost per component (Rs) $\quad: 625=00$

Manufacturing Cost per component (Rs) : $261=00$

Table6

Improved Material, Labor- Capital- Machine and Total Productivity

\begin{tabular}{|c|c|c|c|c|c|c|}
\hline Month & $\begin{array}{l}\text { Revenue from } \\
\text { Production } \\
\text { (Rs) } \\
{[\mathrm{a}]} \\
\end{array}$ & $\begin{array}{c}\text { Material Cost } \\
\text { (Rs) } \\
{[\mathrm{b}]} \\
\end{array}$ & $\begin{array}{l}\text { Labor, Capital \& } \\
\text { Machining Cost } \\
\text { (Rs) } \\
{[\mathrm{c}]} \\
\end{array}$ & $\begin{array}{c}\text { Material } \\
\text { Productivity } \\
{[\mathrm{a} / \mathrm{b}]}\end{array}$ & $\begin{array}{c}\text { Labor, Capital } \\
\text { and Machine } \\
\text { Productivity } \\
{[\mathrm{a} / \mathrm{c}]}\end{array}$ & $\begin{array}{c}\text { Total } \\
\text { Productivity } \\
{[\mathrm{a} / \mathrm{b}+\mathrm{c}]}\end{array}$ \\
\hline March, 2014 & 2627625 & 1718750 & 717750 & 1.5288 & 3.6609 & 1.0784 \\
\hline April,2014 & 2746575 & 1796875 & 750375 & 1.5285 & 3.6602 & 1.0782 \\
\hline May, 2014 & 2386800 & 1562500 & 652500 & 1.5275 & 3.6579 & 1.0775 \\
\hline June, 2014 & 2578875 & 1687500 & 704700 & 1.5282 & 3.6595 & 1.0780 \\
\hline July, 2014 & 2769000 & 1812500 & 756900 & 1.5277 & 3.6583 & 1.0776 \\
\hline Aug, 2014 & 2577900 & 1687500 & 704700 & 1.5276 & 3.6581 & 1.0776 \\
\hline Sep, 2014 & 2723175 & 1781250 & 743850 & 1.5288 & 3.6609 & 1.0784 \\
\hline Oct, 2014 & 2602275 & 1703125 & 711225 & 1.5279 & 3.6588 & 1.0778 \\
\hline Nov, 2014 & 2483325 & 1625000 & 678600 & 1.5282 & 3.6594 & 1.0780 \\
\hline
\end{tabular}

\section{Analysis of Productivity}

The data used in this study for calculating various aspects of productivity was taken from monthly production basis of the company. Using the improved process the company inspects every 10th component instead of every $5^{\text {th }}$ component, due to high accuracy and surface finish achieved on HMC, 
thereby reducing the inspection cost considerably. HMC takes 5.40 minutes including the air cut time in performing the clustered operations. Cycle time of required component viz. Timing Gearbox Cover is coming as 69.3 minutes using improved process and is shown in Table5, which earlier was 82.7 minutes with the existing process as shown in the Table 1.

\section{Effect of improved tooling}

Using combination tooling on HMC, an accurate surface with close dimensional tolerances is easily achievable. Tolerances up to the limit $\pm 0.02 \mathrm{~mm}$ which is closer than the existing tolerance limit of $\pm 0.05 \mathrm{~mm}$ is easily obtainable on the components resulting in low rejection rate. Use of carbide tools on CNC machine instead of using HSS tools on conventional machines has resulted in more than $12 \%$ reduction in tooling cost. The said carbide tools withstand higher temperature and retain their cutting edges for comparatively longer time due to excellent property of red hardness and toughness, consequently resulting in longer tool life. Feed rate and rotational speed have also increased tremendously for performing the same operation.

\section{Statistical comparison of existing process and improved process using control chart for fraction defectives}

The chart used for fraction defective with variable subgroup size is P-Chart. The straight line with ordinate value 0.044 is the centre line, CL of the chart shown in the Fig 2. It is inferred that triangular point for $3^{\text {rd }}$ and $7^{\text {th }}$ sample is comparatively more distant from the centerline, which means the quality of the product is not up to the required level rendering higher fraction defectives and increasing rejection rate. The centerline, CL has ordinate value as 0.0199 and is shown in Fig. 3pertaining to improved process. On interpretation of the graphs for existing and improved process it is apparent that the square points in figure 3 are falling at closer distance to the centerline, CL in improved process. Hence is in better statistical control. Comparison of existing and improved chart has analyzed that monthly fraction defectives variation has reduced for improved process.

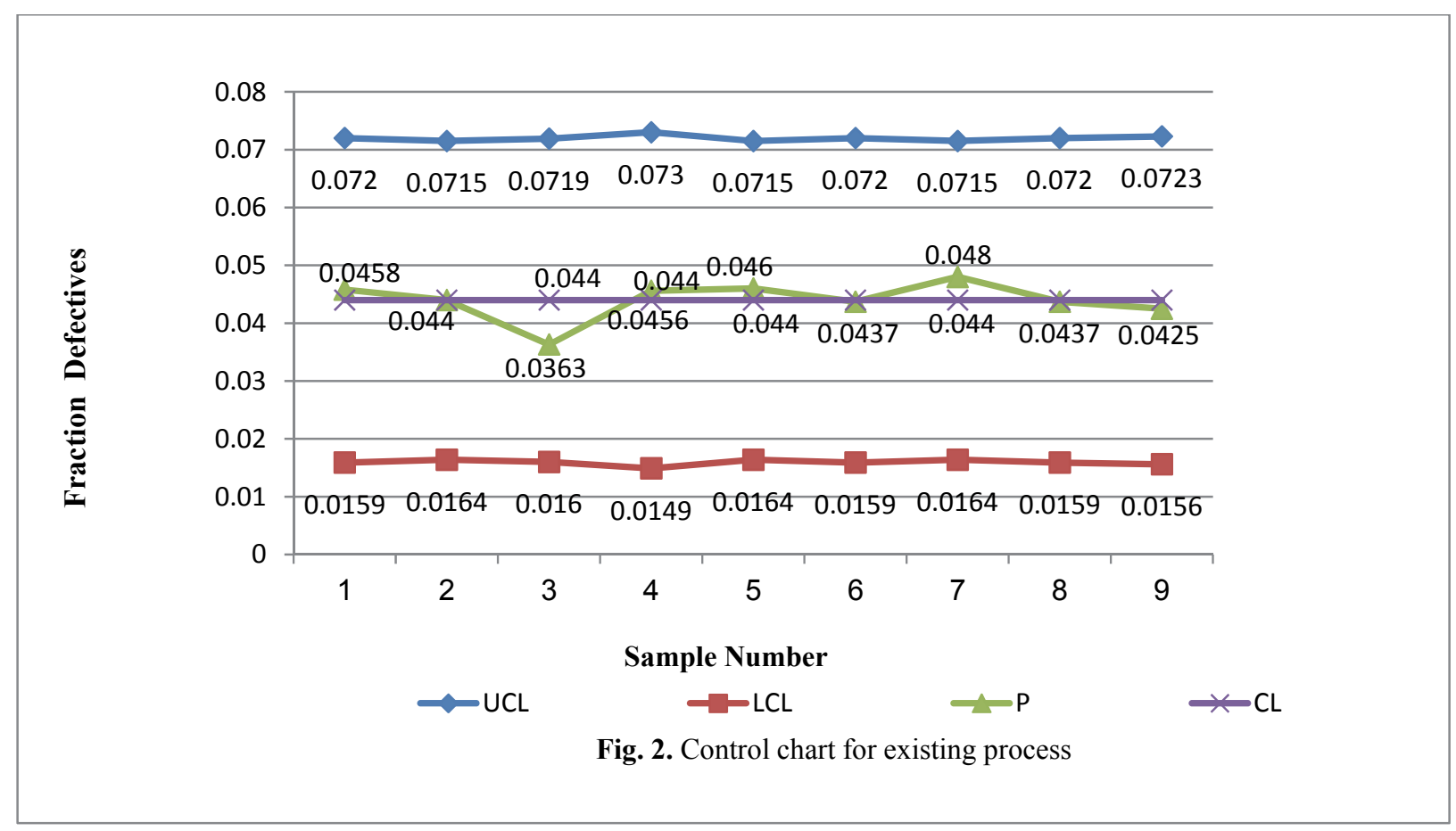




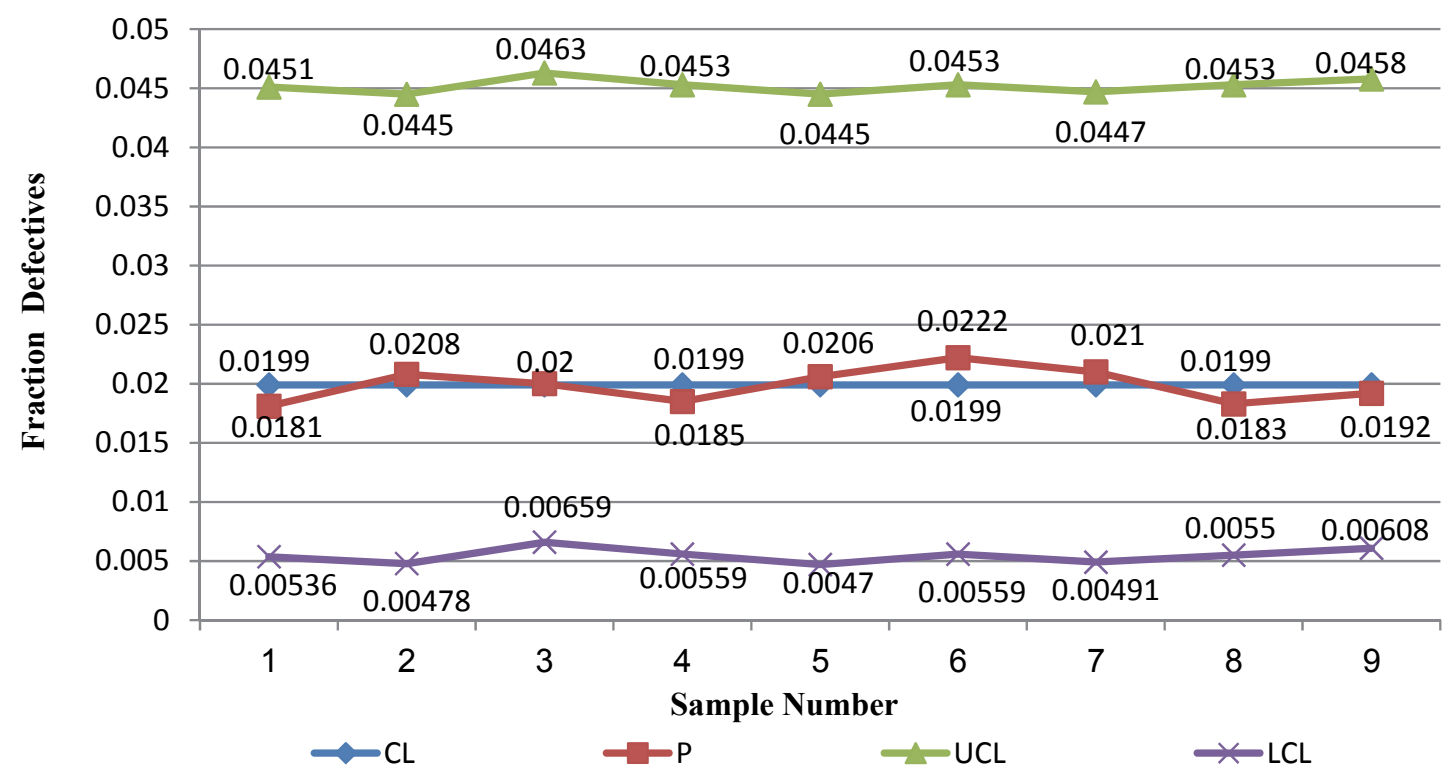

Fig. 3. Control chart for improved process

\section{Conclusion}

Less variation of the curve has been depicted from the interpretation of controlled charts so it is inferred that the process is better statistically controlled. As the number of machines performing the required operations has been reduced from eight to six, chances of error has got reduced due to higher rigidity of the machine. A reduction of $6.78 \%$ in manufacturing cost per component was obtained on account of reduction in cycle time despite of using machines with higher hourly rate of the machines. Tooling cost was reduced by more than $12 \%$ due to increased tool life of carbide tools used on CNC machine. Close dimensional tolerance has also been possible after clustering viz $\pm 0.02 \mathrm{~mm}$, instead of earlier $\pm 0.05 \mathrm{~mm}$ due to reduction in set-ups. Due to reduced cycle time monthly production rate has increased by $16.2 \%$, and rejection rate was lowered by more than $2 \%$ as a result of performing different operations accurately. A total saving of more than 13 minutes in cycle time was observed due to clustering. Consequently material productivity has increased by $2.51 \%$, while capital, labor and machine productivity has increased by $10.01 \%$.Resultantly total productivity has increased by $4.84 \%$.

\section{Acknowledgement}

The authors would like to thank the anonymous referees for constructive comments on earlier version of this paper.

\section{References}

Gunasekaran, A., \& Cecille, P. (1998). Implementation of productivity improvement strategies in a small company. Technovation, 18(5), 311-320.

Gupta, A. (2010). Indian manufacturing productivity: What caused the growth stagnation before the 1990s? International Productivity Monitor, 20, 85-102.

Amir Hanin, Y. (2007). Productivity improvement using one piece flow techniques: A study at An electronic company. 
Fernandes, A. M. (2008). Firm productivity in Bangladesh manufacturing industries. World Development, 36(10), 1725-1744.

Goldar, B., \& Kumari, A. (2002). Import liberalization and productivity growth in Indian manufacturing industries in the 1990s. Growth, Equity, Environment and Population, 94.

Goldar, B. (2004). Productivity trends in Indian manufacturing in the pre-and post-reform periods. Indian Council for Research on International Economic Relations.

Hsieh, C. T., \& Klenow, P. J. (2007). Misallocation and manufacturing TFP in China and India (No. w13290). National Bureau of Economic Research.

Balk, B. M. (2005, December). Annual and quarterly productivity measures. In Economic Measurement Group Workshop sponsored by the Center for Applied Economic Research at the University of New South Wales, the Australian Bureau of Statistics and the Australian Research Council, held at Coogee, Australia (Vol. 1).

Berndt, E. R., \& Fuss, M. A. (1989). Economic capacity utilization and productivity measurement for multi-product firms with multiple quasi-fixed inputs (No. w2932). National bureau of economic research.

Bond, J. T., \& Galinsky, E. (2006). How Can Employers Increase the Productivity and Retention of Entry-Level, Hourly Employees. Research Brief, 2.

Bryson, L. S., Maynard, C., Castro-Lacouture, D., \& Williams, R. L. (2005, April). Fully autonomous robot for paving operations. In Proceedings of the 2005 ASCE Construction Research Congress (pp. 5-7).

Card, D.N. (2006). The challenge of productivity measurement.Proceedings of Pacific Northwest Software Quality Conference, 1-10.

Das, D. K. (2003). Manufacturing productivity under varying trade regimes: India in the 1980s and 1990s. Indian Council for Research on International Economic Relations.

Doo, M., \& Sohn, S. (2008, February). Productivity improvement of manufacturing SMEs via technology innovation in Korea. In 7th WSEAS International Conference on Artificial Intelligence, Knowledge Engineering and Data Bases (AIKED’08) (pp. 20-22).

Dash, M., Kabra, G., \& Singh, A. (2010). Productivity Growth of Manufacturing Sector in India an Inter-State Analysis. European Journal of Scientific Research, 44(3), 387-399.

Faulk, S., Gustafson, J., Johnson, P. M., Porter, A. A., Tichy, W., \& Votta, L. (2004, May). Toward accurate HPC productivity measurement. In Proceedings of the First International Workshop on Software Engineering for High Performance Computing System Applications.

Kaur, M., \& Kiran, R. (2008). Indian manufacturing sector: growth and productivity under the new policy regime. International Review of Business Research Papers, 4(2), 136-150.

Kathuria, V., Raj, R., \& Sen, K. (2010). State business relations and manufacturing productivity growth in India. Available at SSRN 1544290.

Lieberman, M. B., \& Demeester, L. (2002). Inventory reduction and productivity growth: evidence from the Japanese automotive sector.

Motohashi, K., \& Yuan, Y. (2009). IT, R\&D and productivity of Chinese manufacturing firms. In RIETI Working Papers, 09-E-007. Research Institute of Economy, Trade and Industry Tokyo.

Mohaddes, S. A., \& Mazhari, M. (2008). Total and Input Factor Productivity Analysis of Poultry Production in Khorasan Province, Iran. American-Eurasian Journal Agricultural and Environmental Science, 2, 151-4.

Nataraj, S. (2009). The impact of trade liberalization on productivity and firm size distribution: Evidence from India's formal and informal manufacturing sectors.

Sheth, J. N., \& Sisodia, R. S. (2002). Marketing productivity: issues and analysis. Journal of Business Research, 55(5), 349-362.

Sharma,P., Phanden, R.K.,\& Baser, V. (2012). Analysis of site selection based on factors rating. International Journal of Emerging Trends in Engineering and Development, 6(2), 616-622.

Singh, R. P.,\& Singhal, S. (2015). Rotary ultrasonic machining of advanced materials: A review. International Journal for Technological Research in Engineering, 2(7), 777-785. 
Sohail, S. M. (2006). Analysis of Productivity Measures and the Factors Affecting Accurate Measurement of Productivity.

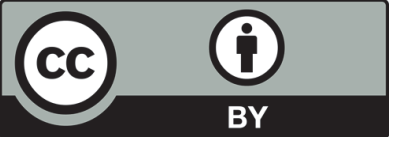

(C) 2016 by the authors; licensee Growing Science, Canada. This article is an open access article distributed under the terms and conditions of the Creative Commons Attribution (CC-BY) license (http://creativecommons.org/licenses/by/4.0/). 